\title{
The Effect of Cardiac Cycle Length on Ventricular End-Diastolic Pressure and Maximum Time Derivative of Pressure in the Stage 24 Chick Embryo
}

\author{
FRANK J. ZIMMERMAN, SHARON F. HUGHES, BETTINA CUNEO, AND
}

D. WOODROW BENSON, JR.

Division of Cardiology, Children's Memorial Hospital, Northwestern University Medical School, and the Feinberg Cardiovascular Research Institute, Chicago, Illinois 60614

\begin{abstract}
We hypothesized that developmental increases in both ventricular end-diastolic pressure (EDP) and the maximum time derivative of pressure $(\mathrm{dP} / \mathrm{dt}) \mathrm{ob}-$ served in stage 12 to 29 chick embryos are the result of observed cardiac cycle length (CL) decrease (heart rate increase). To test this hypothesis, we evaluated EDP and $\mathrm{dP} / \mathrm{dt}$ changes that occur during acute $\mathrm{CL}$ alterations in the Hamburger-Hamilton stage 24 chick embryo $(n=18)$. Ventricular pressure measurements were obtained with a servo-null pressure system and digitally recorded at $\mathbf{5 0 0}$ samples/s. A 1-mm steel probe, heated (decrease $\mathrm{CL}$ ) or cooled (increase $C L$ ), was applied to the sinus venosus. The average baseline $C L$ was $454 \mathrm{~ms}$. The heart rate perturbation resulted in $C L$ that varied over a range of 200-2966 ms, assimilating the range of $\mathrm{CL}$ change observed during development. Changes in EDP ranged from 0.014 to $0.130 \mathrm{kPa}$ (baseline $=0.061 \mathrm{kPa}$ ) and maximum $\mathrm{dP} / \mathrm{dt}$ ranged from 0.33 to $13.33 \mathrm{kPa} / \mathrm{s}$ (baseline $=5.99$ ) $\mathrm{kPa} / \mathrm{s})$. In each study, EDP varied directly with $\mathrm{CL}\left(\boldsymbol{R}^{2}=\right.$ $0.70)$. Conversely, maximum $\mathrm{dP} / \mathrm{dt}$ changes were inversely related to $C L$ alterations $\left(R^{2}=0.54\right)$. Thus, we found that there is a direct relationship between changes in $C L$ and EDP in the stage 24 chick embryo, whereas $C L$ and $\mathrm{dP} / \mathrm{dt}$ vary inversely. During cardiac development, observed increases in maximum $\mathrm{dP} / \mathrm{dt}$ may be attributed to $\mathrm{CL}$ decreases. In contrast, developmental increases in EDP cannot be explained by $\mathrm{CL}$ decrease and must be accounted for by maturational changes in cardiac function in the chick embryo. (Pediatr Res 29: 338-341, 1991)
\end{abstract}

Abbreviations

EDP, end-diastolic-pressure

$\mathrm{dP} / \mathrm{dt}$, time derivative of pressure

$\mathrm{CL}$, cardiac cycle length

Cardiac maturation in the developing embryo is a dynamic process involving complex structural changes accompanied by dramatic changes in hemodynamic function. During cardiac development of the chick embryo, for example, Hu and Clark

Received July 27, 1990; accepted November 7, 1990

Correspondence: D. Woodrow Benson, Jr., M.D., Ph.D., Division of Cardiology, Children's Memorial Hospital, 2300 Children's Plaza, Chicago, IL 60614.

Supported in part by a grant from the American Heart Association (89-0886) and the Walden W. and Jean Young Shaw Foundation.
(1) have shown that increases in both ventricular EDP and maximum $\mathrm{dP} / \mathrm{dt}$ occur concurrently with $\mathrm{CL}$ decrease (heart rate increase) from d 2 to 6 (Hamburger-Hamilton stages 12 to 29) of a $21-d$ incubation.

We wondered to what extent the developmental changes in $\mathrm{EDP}$ and $\mathrm{dP} / \mathrm{dt}$ might reflect observed changes in $\mathrm{CL}$. The purpose of this study, therefore, is to examine whether the observed increases in both EDP and $\mathrm{dP} / \mathrm{dt}$ are a function of the observed decrease in CL. We evaluated EDP and maximum dP/ $\mathrm{dt}$ during acute $\mathrm{CL}$ alterations in the stage 24 (d 4) chick embryo. By studying these relationships in a single stage of development, the effect of $\mathrm{CL}$ alteration can be assessed independently of other effects secondary to changes in cardiac morphology.

\section{MATERIALS AND METHODS}

Fertile White Leghorn chicken eggs were incubated to Hamburger-Hamilton stage $24(4 \mathrm{~d})$ at $38^{\circ} \mathrm{C}(2)$. An egg was removed from the incubator and placed in a heated sand bath (Bioengineering Department, Medical College of Georgia) under a radiant warmer to maintain a constant egg temperature of $37-38^{\circ} \mathrm{C}$ throughout the experiment. The embryo was exposed by removing a portion of the shell and the overlying membranes. The CL was altered using a 1-mm stainless steel probe that was first heated or cooled in a water bath. The probe was then placed on the sinus venosus for $10 \mathrm{~s}$ to shorten or lengthen the $\mathrm{CL}$. An additional 10 control studies were performed using a probe at $37-38^{\circ} \mathrm{C}$ to exclude pressure of the probe as a cause for any alteration in hemodynamics.

Ventricular pressure was measured with a servo-null micropressure system (model 900; WP Instruments, New Haven, CT) from a drawn glass micropipette (tip diameter $=7 \mu \mathrm{m}$ ) inserted directly into the ventricle. The micropressure system had been validated against a water column and in vitro measurements were found to be linear over a range of 0 to $6.67 \mathrm{kPa}(0-50 \mathrm{~mm} \mathrm{Hg})$. Signals were amplified using a direct current amplifier (model 319D; BMT Instruments, Southold, NY) and digitally recorded at 500 samples/s. The $\mathrm{dP} / \mathrm{dt}$ was derived from the pressure curve using numerical differentiation (Computerscope; RC Electronics, Santa Barbara, CA) (Fig. 1). Zero trans-tip pressure was established by immersing the electrode in the extraembryonic fluid at the level of the heart. Records from embryos that did not recover to within $10 \%$ of the baseline CL or in which the baseline pressure measurements were not stable throughout the experiment were discarded.

The data were evaluated using multiple regression analysis. 
Quadratic regression lines for each of the 18 cases were generated for EDP versus $\mathrm{CL}$ and $\mathrm{dP} / \mathrm{dt}$ versus $\mathrm{CL}$. Control studies were analyzed using paired $t$ tests.

\section{RESULTS}

For the 18 embryos, the baseline (mean \pm SEM) value for $\mathrm{CL}$ was $453 \pm 3.8 \mathrm{~ms}$, the mean EDP was $0.061 \pm 0.001 \mathrm{kPa}$ and the mean of the maximum $\mathrm{dP} / \mathrm{dt}$ was $5.76 \pm 0.16 \mathrm{kPa} / \mathrm{s}$. Recordings of EDP and $\mathrm{dP} / \mathrm{dt}$ during placement of a heated and cooled probe are shown in Fig. 2. During placement of a probe at $37-38^{\circ} \mathrm{C}$ (control), the $\mathrm{CL}$ changed $<5 \%$ and EDP and $\mathrm{dP} / \mathrm{dt}$ changes were not significant.

Application of the hot probe resulted in a minimum CL of $200 \mathrm{~ms}$, whereas application of the cold probe resulted in a maximum CL of $2966 \mathrm{~ms}$. However, CL $>1500 \mathrm{~ms}$ were observed in only four embryos for a total of only 22 out of 2254 data points. Because of the very small sample size at extremely

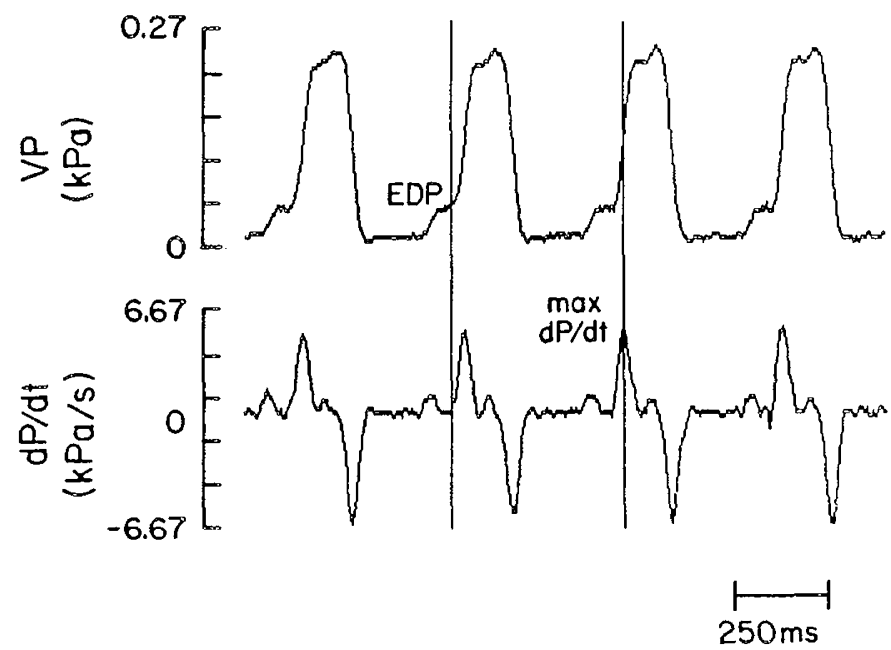

Fig. 1. Example tracings of ventricular pressure $(V P)$ and digitally derived $\mathrm{dP} / \mathrm{dt}$. EDP and maximum $\mathrm{dP} / \mathrm{dt}$ are measured at the points indicated.
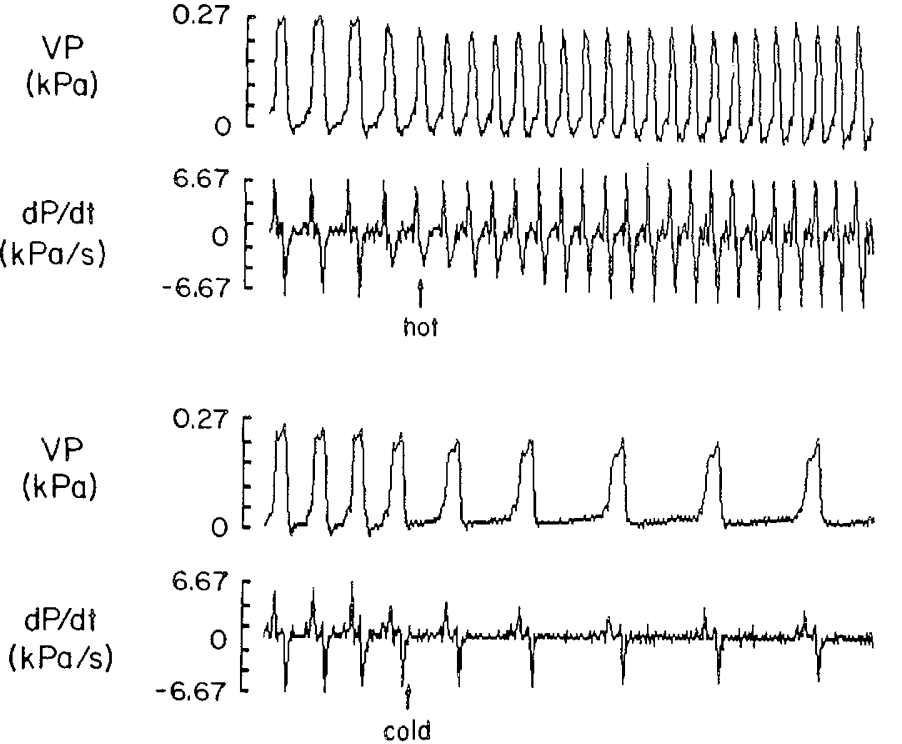

Fig. 2. Recordings during probe placement. During hot probe placement (top tracing), the cycle length decreased from 447 to $240 \mathrm{~ms}$. During cold probe placement (bottom tracings), the cycle length increased from 447 to $1340 \mathrm{~ms}$. VP, ventricular pressure. long $\mathrm{CL}$ and because of the shortcomings of the quadratic regression model at very long $\mathrm{CL}$, these points were discarded and the reported results are limited to $\mathrm{CL}<1500 \mathrm{~ms}$.

Results from a single study show that as the $\mathrm{CL}$ increased, the EDP asymptotically increased (Fig. $3 A$ ). The regression line for each study and a composite regression line for all studies is shown in Figure $3 B$. For the 18 embryos, the average EDP increased from 0.043 to $0.092 \mathrm{kPa}$ as the $\mathrm{CL}$ increased from 200 to $1500 \mathrm{~ms}$.

On the other hand, results from a single study show that maximum $\mathrm{dP} / \mathrm{dt}$ asymptotically decreased as CL increased (Fig. $4 A$ ). The regression for each study and a composite regression line for all studied is shown in Figure $4 B$. For the 18 embryos, the average maximum $\mathrm{dP} / \mathrm{dt}$ decreased from 6.67 to $3.20 \mathrm{kPa} / \mathrm{s}$ as the $\mathrm{CL}$ increased from 200 to $1500 \mathrm{~ms}$.

\section{DISCUSSION}

Our study was designed to test the hypothesis that observed developmental increase in ventricular EDP and maximum $\mathrm{dP} /$ $\mathrm{dt}$ are the result of concurrent changes in cardiac CL. We found that in the stage 24 chick embryo the EDP increased as CL increased. This direct relationship is contrary to that observed during embryonic development. However, the maximum $\mathrm{dP} / \mathrm{dt}$ decreased when $C L$ increased, which is similar to the reciprocal relationship observed during development. Only acute CL changes were observed in our study. It is not clear if chronic CL changes would have similar effects on EDP and $\mathrm{dP} / \mathrm{dt}$.
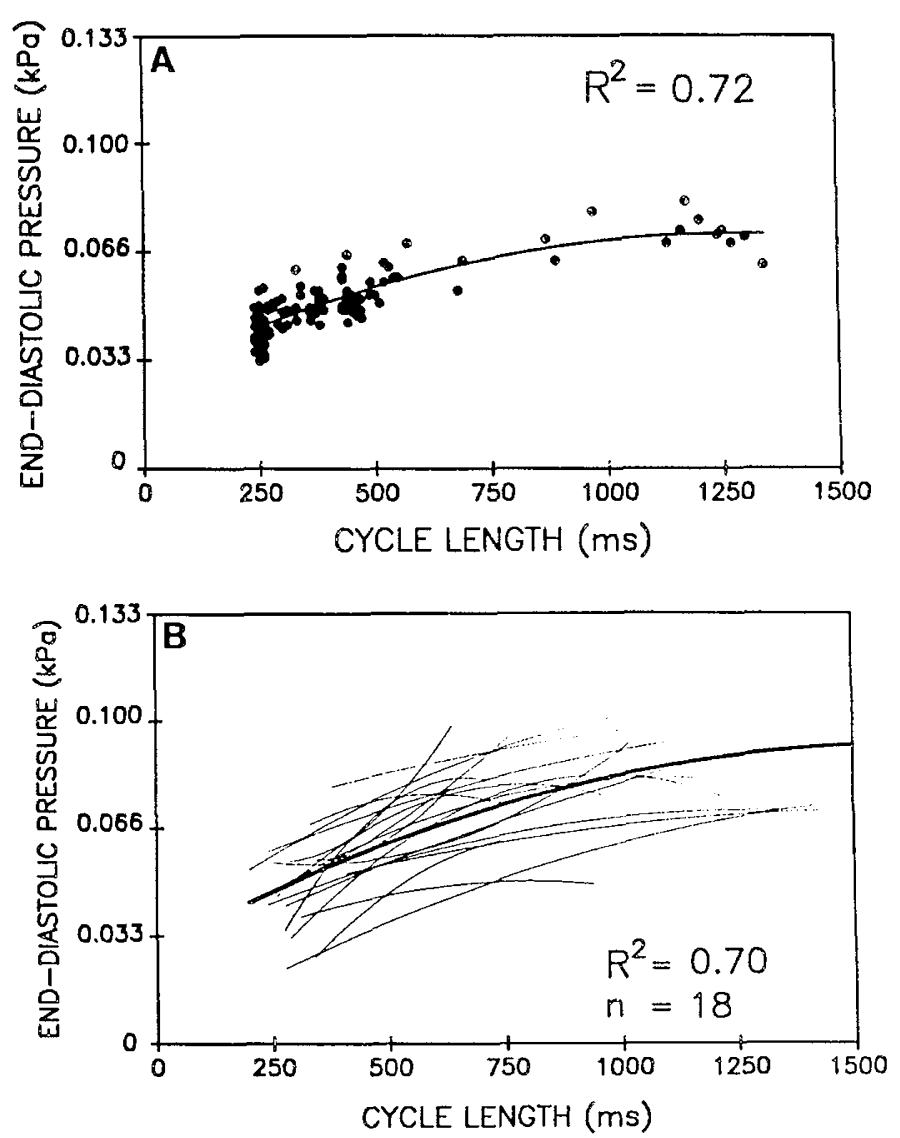

Fig. 3. Relationship of EDP and CL. Panel $A$ shows a quadratic regression plot of the relation between EDP and $\mathrm{CL}$ for a single embryo. The $R^{2}$ of the regression curve is 0.72 . Panel $B$ shows a composite plot of the relation of EDP to cycle length. The thin lines represent the individual regression curves for each of the 18 embryos. The thick line is the regression curve for all data points. The $R^{2}$ of the average regression is 0.70 . 

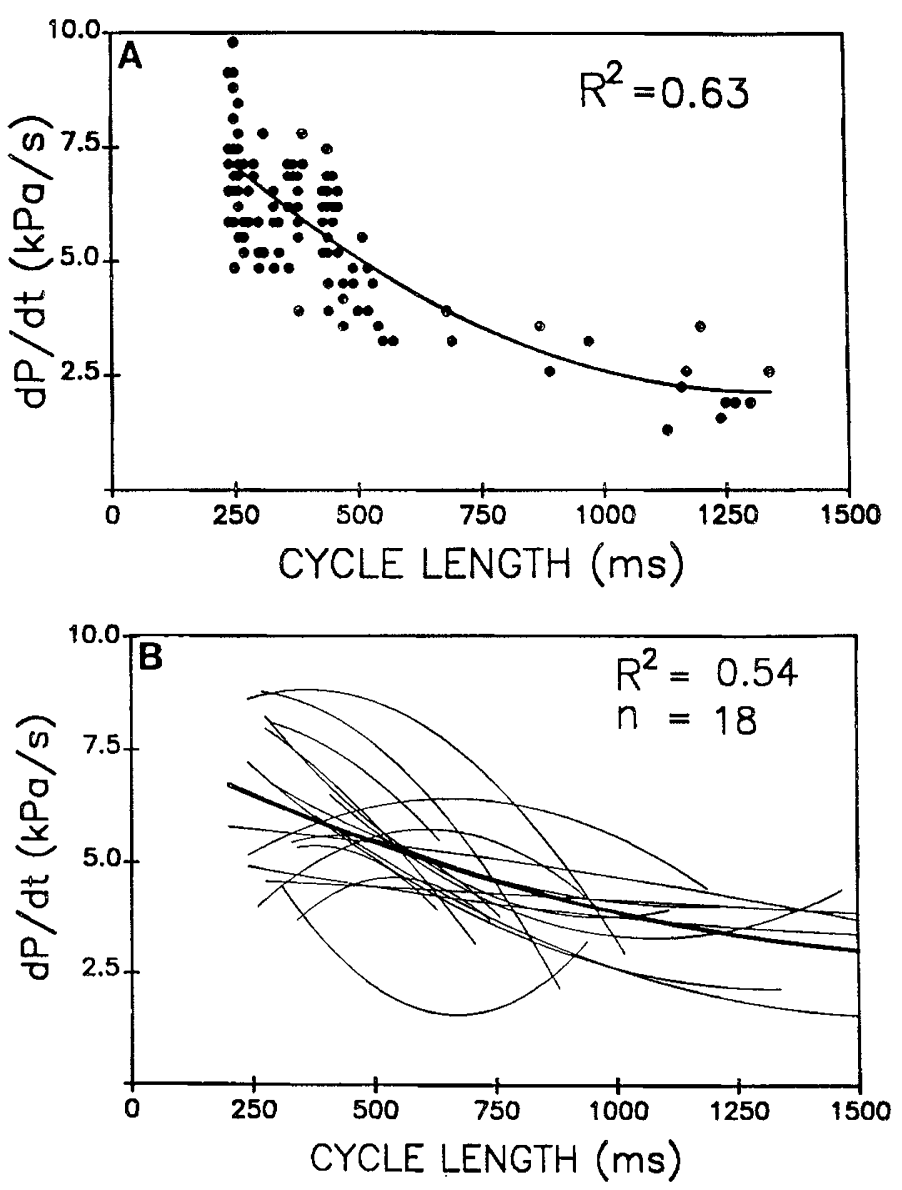

Fig. 4. Relationship of maximum $\mathrm{dP} / \mathrm{dt}$ and $\mathrm{CL}$. Panel $A$ shows a quadratic regression plot of the relation between $\mathrm{dP} / \mathrm{dt}$ and $\mathrm{CL}$ for a single embryo. The $R^{2}$ of the regression curve is 0.63 . Panel $B$ shows a composite plot of the relation of maximum $\mathrm{dP} / \mathrm{dt}$ to cycle length. The thin lines represent the individual regression curves for each of the 18 embryos. The thick line is the regression curve for all data points. The $R^{2}$ of the average regression is 0.54 .

The relationship between maximum $\mathrm{dP} / \mathrm{dt}$ and $\mathrm{CL}$ found in the stage 24 embryo suggests that maximum $\mathrm{dP} / \mathrm{dt}$ increase during developmental stages 12 to 29 may be a function of developmental CL decrease, exclusive of structural changes occurring to the embryonic heart.

The positive inotropic effect of decreasing the CL (so-called "treppe" phenomenon) was first described by Bowditch (3). This relationship has since been recognized in the fetal, neonatal, and mature mammalian heart $(4,5)$. Results of our study show a similar relationship in the stage 24 embryonic chick heart.

As previously reviewed (5), most studies in the fetal, neonatal, and mature mammalian heart report a decrease or no change in EDP during CL decrease. A similar relationship was found in this study for the stage 24 chick embryo. Thus, developmental EDP increase cannot be accounted for by CL decrease. Developmental EDP increase might be the result of changes in cardiac geometry-morphology, myocyte function, or both. In the chick embryo, the heart develops from a thin-walled tube at stage 12 to a sponge-like single ventricle at stage 24 and finally to a thickwalled, four-chambered pump at stage $29(6)$. During the same developmental stages, the average weight of the ventricles increases 30 -fold from 0.1 (stage 12) to $3.18 \mathrm{mg}$ (stage 29), and the average weight of embryo increases 100 -fold from 2.22 to 267.5 $\mathrm{mg}$, respectively $(1,7)$. The ventricular shortening fraction changes very little (8). Diastolic functional changes associated with these dramatic changes in cardiac structure include an increase in EDP as well as a decrease in the ratio of passive to active filling components of the atrioventricular filling velocity (9). The later change has been interpreted as indicating a decrease in the compliance of the ventricle as the embryo matures. A compliance decrease might account for the observed developmental increase in EDP. We did not evaluate compliance in this study as we did not measure ventricular volume.

Rapid changes at the myocyte level also occur during embryonic chick cardiac development. Myocytes begin to develop myofibrils during stages 9 or 10; initially there is an increase in the proportion of myofibril-cell volume, but then a decrease as myofibrils become more organized presumably by aligning along lines of stress (7). There appears to be little or no change in ventricular myofibrillar myosin during cardiogenesis of the chick embryo (10). On the other hand, developmental studies of myocardial calcium transport have shown that sarcolemmal $\mathrm{Na}-\mathrm{Ca}$ exchange is the primary mechanism of calcium transport in the young chick embryo, whereas sarcoplasmic reticulum calcium uptake plays the predominate role in calcium transport in the newborn and adult chicken (11). It is possible that developmental changes in the calcium transport network and their role in ventricular relaxation contribute to the developmental changes in ventricular EDP.

Use of the thermal probe technique for heart rate perturbation avoids some of the problems encountered by methods previously employed to alter CL. Environmental hypothermia (12) and hyperthermia (13) affect the systemic vascular resistance as well as alter the CL. The thermal probe limits temperature effects to the sinus venosus, resulting in an isolated CL change. Previous studies with the thermal probe technique showed that there is a linear relationship between CL and stroke volume (14). The CL and stroke volume relationship is identical for heart rate increase with sinus venosus pacing or application of a heated probe. Sinus venosus pacing alters $C L$, but the electronic interference of the pacing stimulus prevents pressure measurement with the servonull system (15).

Defining the relationship between form and function of the developing cardiovascular system is important to understanding the formation of the heart. Further investigation of the hemodynamic, morphologic, and cellular changes occurring in the embryonic heart will help to delineate normal and abnormal mechanisms of development.

\section{REFERENCES}

1. Hu N, Clark EB 1989 Hemodynamics of the stage 12 to stage 29 chick embryo. Circ Res 65:1665-1670

2. Hamburger V, Hamilton HL 1951 A series of normal stages in the development of the chick embryo. J Morphol 88:49-92

3. Graber JD, Conti CR, Lappe DL, Ross RS 1972 Effect of pacing-induced tachycardia and myocardial ischemia on ventricular pressure-velocity relationships in man. Circulation 46:74-83

4. Anderson PAW, Manring A, Crenshaw Jr C 1980 Biophysics of the developing heart. I. The force-interval relationship. Am J Obstet Gynecol 138:33-43

5. Fisher DJ, Gross DM 1983 The effect of atrial pacing-induced tachycardia on left ventricular contractile function in conscious newborn and adult sheep. Pediatr Res 17:651-656

6. Ben Shachar G, Arcilla A, Lucas RV, Manasek FJ 1985 Ventricular trabeculations in the chick embryo heart and their contribution to ventricular and muscular septal development. Circ Res 57:759-766

7. Clark EB, Hu N, Dummett JL, Vandedieft GK, Olson C, Tomanek R 1986 Ventricular function and morphology in chick embryos from stages 18 to 29. Am J Physiol 250:H407-H413

8. Keller BB, Hu N, Clark EB 1990 Correlation of ventricular area, perimeter, and conotruncal diameter with ventricular mass and function in the chick embryo from stages 12 to 24 . Circ Res 66:109-114

9. Meijboom EJ, Hu N, Clark EB 1988 Atrioventricular velocity characteristics in the stage 18 to 27 chick embryo. Circulation 78:444(abstr)

10. Sweeney LJ, Zak R, Manasek FJ 1987 Transitions in cardiac isomyosin expression during differentiation of the embryonic chick heart. Circ Res 61:287-295

11. Vetter R, Will H 1986 Sarcolemmal $\mathrm{Na}-\mathrm{Ca}$ exchange and sarcoplasmic retic- 
ulum calcium uptake in developing chick heart. J Mol Cell Cardiol 18:12671275

12. Nakazawa M, Clark EB, Hu N, Wispe J 1985 Effect of environmental hypothermia on vitelline artery blood pressure and vascular resistance in the stage 18, 21, and 24 chick embryo. Pediatr Res 19:651-654

13. Nakazawa M, Miyagawa S, Takao A, Clark EB, Hu N 1986 Hemodynamic effects of environmental hyperthermia in stage 18,21, and 24 chick embryos. Pediatr Res 20:1213-1215

14. Cuneo $B$, Hughes $S$, Benson $\mathrm{J}_{\mathbf{r}}$ DW 1989 Heart rate change in stage 24 chick embryos: effect on stroke volume. Am J Cardiol 64:413(abstr)

15. Dunnigan, Hu N, Benson Jr DW, Clark EB 1987 Effect of heart rate increase on dorsal aortic flow in the stage 24 chick embryo. Pediatr Res 22:442-444

\section{Announcement}

\section{Annual Meeting of the European Society for Pediatric Research 1991}

The European Society for Pediatric Research (ESPR) will hold its next meeting in Zürich, Switzerland, September 1-4, 1991. The European Society of Pediatric Allergy and Clinical Immunology and the European Society of Magnetic Resonance in Neuropediatrics will join the ESPR. Satellite postgraduate courses and a symposium will be organized by these two societies on September 1 and September 5.

The main topics of the ESPR meeting are: therapeutic interventions in immune-mediated diseases, connective tissue, energy metabolism, and circulation of the neonatal brain.

Deadline for submitting abstracts is April 15, 1991.

For information, contact: Gabriel Duc, University Hospital of Zürich, Frauenklinikstrasse 10, ZH-8091 Zürich, Tel. +4112555340 , Telefax +4112554442 . 


\title{
Effect of a Ring-Deleted Atrial Natriuretic Factor Analogue on Ovine Fetal Renal and Cardiovascular Function ${ }^{1}$
}

\author{
ROBERT CASTRO, M. GORE ERVIN, ROSEMARY D. LEAKE, MICHAEL G. ROSS, AND \\ DELBERT A. FISHER \\ Perinatal Physiology Laboratories, Departments of Pediatrics and Obstetrics and Gynecology, UCLA School of \\ Medicine, Harbor-UCLA School of Medicine, Harbor-UCLA Medical Center, Torrance, California 90509
}

\begin{abstract}
The proposed actions of atrial natriuretic factor (ANF) are mediated through specific plasma membrane $\left(R_{1}\right)$ receptors coupled to guanylate cyclase. A second receptor, $\mathbf{R}_{2}$, has been characterized by its ability to bind to an acyclic, truncated ANF analog $\left(\mathrm{C}-\mathrm{ANF}_{4-23}\right)$. The $A N F-R_{2}$ receptor has not been identified in the fetus. Our study was conducted to determine the effects of C-ANF on fetal renal and cardiovascular function and plasma ANF clearance rates. Chronically catheterized ovine fetuses $(n$ $=6$ ) at 111 to $117 \mathrm{~d}$ gestation (term $145 \mathrm{~d}$ ) received a $\mathrm{C}$ ANF infusion $(1 \mu \mathrm{g} / \mathrm{min} / \mathrm{kg})$ for $30 \mathrm{~min}$ followed by a combined infusion of C-ANF and ANF (C-ANF, $1 \mu \mathrm{g} / \mathrm{min} /$ $\mathrm{kg}$; ANF, $100 \mathrm{ng} / \mathrm{min} / \mathrm{kg}$ ) for an additional $30 \mathrm{~min}$. C-ANF infusion significantly increased (mean \pm SEM) plasma ANF concentration $(437 \pm 45$ to $1067 \pm 297 \mathrm{pg} / \mathrm{mL})$, urinary flow rate $(0.26 \pm 0.04$ to $0.38 \pm 0.07 \mathrm{~mL} / \mathrm{min} / \mathrm{kg}$ ), sodium excretion $(12.9 \pm 3.5$ to $21.7 \pm 6.1 \mu \mathrm{mol} / \mathrm{min} / \mathrm{kg})$, and osmolar clearance $(0.14 \pm 0.02$ to $0.21 \pm 0.04 \mathrm{~mL} /$ $\mathrm{min} / \mathrm{kg})(p<0.05)$. The combined C-ANF/ANF infusion further increased plasma ANF concentration to $2394 \pm$ $532 \mathrm{pg} / \mathrm{mL}$ and resulted in significant increases in urinary flow rate, sodium excretion, osmolar clearance, GFR, and free water clearance compared with C-ANF infusion alone $(p<0.05)$. These renal responses, however, were not significantly different from the responses to ANF infusion alone $(100 \mathrm{ng} / \mathrm{min} / \mathrm{kg})$. Although the calculated mean ANF plasma clearance rate during the combined C-ANF/ANF infusion $(77 \pm 16 \mathrm{~mL} / \mathrm{min} / \mathrm{kg})$ was lower than previously observed in more mature fetal lambs, the value was not different from the mean ANF plasma clearance rate calculated during ANF infusion alone $(68 \pm 15 \mathrm{~mL} / \mathrm{min} / \mathrm{kg})$. The response to the $C$-ANF infusion suggests displacement of ANF from renal ANF- $R_{2}$ receptors, supporting the presence of $R_{2}$ receptors in the ovine fetus. However, these findings indicate that receptor-mediated ANF clearance does not significantly contribute to overall fetal plasma ANF clearance at this early gestational age. (Pediatr Res 29: 342-346, 1991)
\end{abstract}

\section{Abbreviations}

ANF, atrial natriuretic factor C-ANF, 4-23 (truncated) ANF

Received May 18, 1990; accepted November 20, 1990.

Correspondence and reprint requests: Delbert A. Fisher, M.D., Harbor-UCLA Medical Center, Walter P. Martin Research Building, 1000 West Carson Street, Torrance, CA 90509

Supported in part by Grants HD 06335 and HL 40899 from the National Institute of Child Health and Human Development, National Institute of Health. R.C. is the recipient of a grant from the Robert Wood Johnson Foundation Medical Minority Faculty Development Program.

Presented in part at the Annual Meeting of the Society for Pediatric Research Anaheim, CA, May 1990
$\mathrm{PC}_{\mathrm{ANF}}$, ANF plasma clearance rate

The cardiac atria secrete a group of structurally related peptides, termed ANF, that evoke potent natriuretic, diuretic, and vasodilatory effects in adult animals and man $(1,2)$. The multiple effects of ANF are mediated through specific plasma membrane receptors located in numerous target tissues, including vascular endothelial and smooth muscle cells, renal glomerular epithelial and mesangial cells, the renal papillae, adrenal, and pituitary glands, and various brain regions (3). At least two distinct types of ANF receptors have been proposed based on estimates of receptor size. One receptor, $R_{1}$, is coupled to guanylate cyclase and is proposed to mediate the known physiologic actions of ANF on target tissues through the production of cyclic GMP (4). A second ANF receptor, $R_{2}$, is not coupled to guanylate cyclase and is characterized by its ability to bind to various truncated and ring-deleted analogs of $\operatorname{ANF}(5,6)$. Although the ANF-R receptors have been postulated to serve an ANF storage/clearance function (7), recent data indicate that ANF binding to these receptors stimulates phosphoinositol hydrolysis (8) and inhibits adenylate cyclase and cAMP production (9). The significance of these second messenger effects is not yet clear.

The ontogeny and function of ANF receptors during fetal maturation have not been extensively studied. Placental (ANF) receptors have been isolated in various mammalian species (10, 11) including man (12). Renal glomerular ANF receptors have been described as early as $108 \mathrm{~d}$ gestation in the ovine fetus (term $=145 \mathrm{~d}$ ); ANF binding capacity of the glomerular receptor was shown to increase with gestational age (13). However, the physiologic significance of the placental and glomerular receptors is unclear. The ANF- $R_{2}$ receptor has not been identified in the fetus. In the present paper, we report studies of the effects of $\mathrm{C}$ ANF (an ANF- $R_{2}$ receptor ligand) on ANF kinetics and actions in the fetal sheep conducted to assess the presence and possible significance of fetal ANF- $R_{2}$ receptors.

\section{MATERIALS AND METHODS}

Animals and surgery. Six Western cross-bred pregnant ewes with singleton fetuses ranging in age from 111 to $117 \mathrm{~d}$ (mean gestational age $114 \pm 1 \mathrm{~d}, n=6$ ) were studied. Ovine fetuses at this early gestation have been previously shown to be more responsive to the elevation of plasma ANF concentration than older fetuses or newborn lambs $(14,15)$. Animals were housed indoors in individual steel study cages and maintained under a controlled lighting regimen ( $12 \mathrm{~h}$ of light and $12 \mathrm{~h}$ of dark). Both food (alfalfa pellets) and water were available ad libitum, except that food was withheld during the 24 -h period immediately preceding surgery. 
Anesthesia for surgery was induced by an intramuscular injection of ketamine hydrochloride $(10 \mathrm{mg} / \mathrm{kg})$ plus atropine sulfate $(30 \mu \mathrm{g} / \mathrm{kg}$ ), and subsequently maintained by a continuous i.v. ketamine infusion $(15 \mathrm{mg} / \mathrm{k} / \mathrm{kg})$. Xylocaine $(1 \%)$ was applied locally before all incisions. The pregnant ewe's uterus was exposed by a midline abdominal incision and a small hysterotomy was performed to provide access to a single fetal hindlimb. Tygon catheters ( $1 \mathrm{~mm}$ inner diameter; $1.8 \mathrm{~mm}$, outer diameter) were placed in the fetal dorsal hindlimb vein and artery and threaded to the inferior vena cava and abdominal aorta, respectively. Before hysterotomy closure, a plastic catheter (Corometrics Medical Systems, Wallingford, CT) was sutured to the distal tip of the fetal hindlimb to measure amniotic fluid pressure. The hindlimb was returned into the uterus and the hysterotomy was closed in two layers.

A second hysterotomy was performed to provide access to the fetal abdomen. The fetal abdomen was incised longitudinally (4 $\mathrm{cm}$ ) and the fetal skin marsupialized to the uterus with clamps. The fetal bladder was exposed and $1.5 \mathrm{~cm}$ of a Tygon catheter (inner diameter $=1.3 \mathrm{~mm}$, outer diameter $=2.3 \mathrm{~mm}$ ) with multiple ports was secured to the lining of the bladder by a pursestring suture. The fetal peritoneum and skin were closed as separate layers around the bladder catheter. The uterus, maternal fascia, and skin were closed in separate layers with sutures. The maternal femoral artery and vein were catheterized in one leg and the catheters threaded to the aorta and inferior vena cava, respectively.

All catheters were exteriorized to the maternal flank and placed in a cloth pouch sewn to the ewe's flank. Fetal vascular catheters were maintained patent by filling the catheter dead space $(1 \mathrm{~mL})$ with $1000 \mathrm{U} / \mathrm{mL}$ sodium heparin; catheters were sealed with sterile plastic caps. Maternal vascular catheters were filled with heparinized saline $(10 \mathrm{U} / \mathrm{mL})$ and both fetal and maternal catheters were flushed daily. Immediately after surgery, as well as twice daily for the succeeding $7 \mathrm{~d}$, fetuses received an i.v. infusion of oxacillin (100 mg) and gentamicin $(8 \mathrm{mg})$; oxacillin $(400 \mathrm{mg})$, gentamicin $(72 \mathrm{mg})$, and chloramphenicol $(500 \mathrm{mg})$ also were administered into the maternal vein and amniotic cavity.

Experimental protocol. All experiments were performed on unanesthetized ewes standing in the same individual cages in which they were maintained. Fetal studies were undertaken only if the fetal arterial $\mathrm{pH}$ was greater than 7.35 and the fetal urine osmolality was less than $170 \mathrm{mosmol} / \mathrm{kg}$ water. Both values are sensitive markers of fetal well being.

Experiments were initiated by allowing the fetal bladder catheters to drain by gravity and beginning i.v. infusions of $0.9 \%$ $\mathrm{NaCl}(0.05 \mathrm{~mL} / \mathrm{min} / \mathrm{kg})$ and ${ }^{3} \mathrm{H}$-inulin $(10 \mu \mathrm{Ci} / \mathrm{h})$ in $0.9 \% \mathrm{NaCl}$ $(0.12 \mathrm{~mL} / \mathrm{min})$. After equilibration for $30 \mathrm{~min}$, fetal urine was collected at 10 - min intervals for $30 \mathrm{~min}$ (control period; time $=$ 0 to $30 \mathrm{~min})$. During the subsequent $30 \mathrm{~min}, 0.9 \% \mathrm{NaCl}(0.05$ $\mathrm{mL} / \mathrm{min} / \mathrm{kg}$ ) containing synthetic C-ANF (4-23) (Bachem Inc., Torrance, CA) was administered to the fetuses $(n=6)$ at $1 \mu \mathrm{g} /$ $\mathrm{min} / \mathrm{kg}$ (30 to $60 \mathrm{~min}$ ). This dose of C-ANF was selected on the basis of the experience of Maack et al. (7), who demonstrated major increases in plasma ANF levels and urinary sodium excretion after its administration to intact rats. Fetuses then received a combined infusion of C-ANF $(1 \mu \mathrm{g} / \mathrm{min} / \mathrm{kg})$ and ANF $(100$ $\mathrm{ng} / \mathrm{min} / \mathrm{kg}$ ) for an additional $30 \mathrm{~min}(60$ to $90 \mathrm{~min}$ ). After the $\mathrm{C}-\mathrm{ANF} / \mathrm{ANF}$ infusion, the fetuses received $0.9 \% \mathrm{NaCl}$ infusions and were monitored for an additional 30 -min recovery period (90 to $120 \mathrm{~min}$ ). To compare the physiologic responses, ANF alone $(100 \mathrm{ng} / \mathrm{min} / \mathrm{kg})$ was infused into the same six catheterized fetuses randomly on either the previous or subsequent day using the same protocol. Fetal time-control experiments with $0.9 \%$ $\mathrm{NaCl}$ (vehicle) infusion at $0.05 \mathrm{~mL} / \mathrm{min} / \mathrm{kg}$ and ${ }^{3} \mathrm{H}$-inulin $(10$ $\mu \mathrm{Ci} / \mathrm{h}$ ) in $0.9 \% \mathrm{NaCl}$ at $0.12 \mathrm{~mL} / \mathrm{min}$ were performed in five fetuses using a similar protocol. Infusion concentrations were based on estimated fetal body weight (FBW) from the following formula (14):
Table 1. Maternal arterial blood and plasma values before and after C-ANF and C-ANF/ANF infusion in fetal sheep $(n=6)^{*}$

\begin{tabular}{lcc}
\hline & Control & Recovery \\
\hline $\mathrm{pH}$ & $7.50 \pm 0.02$ & $7.49 \pm 0.02$ \\
$\mathrm{PO}_{2}(\mathrm{~mm} \mathrm{Hg}) \dagger$ & $92 \pm 4$ & $86 \pm 4$ \\
$\mathrm{PCO}_{2}(\mathrm{~mm} \mathrm{Hg})$ & $32 \pm 2$ & $33 \pm 2$ \\
$\mathrm{Hematocrit} \%)$ & $32 \pm 1$ & $32 \pm 3$ \\
Plasma osmolality (mosmol/ & $296 \pm 2$ & $296 \pm 2$ \\
$\mathrm{~kg} \mathrm{H} \mathrm{H}_{2} \mathrm{O}$ & & \\
Plasma ANF $(\mathrm{pg} / \mathrm{mL})$ & $85 \pm 17$ & $75 \pm 22$ \\
\hline
\end{tabular}

$*$ Values are mean $\pm \mathrm{SE}$

$\dagger 1 \mathrm{~mm} \mathrm{Hg}=0.133 \mathrm{kPa}$.

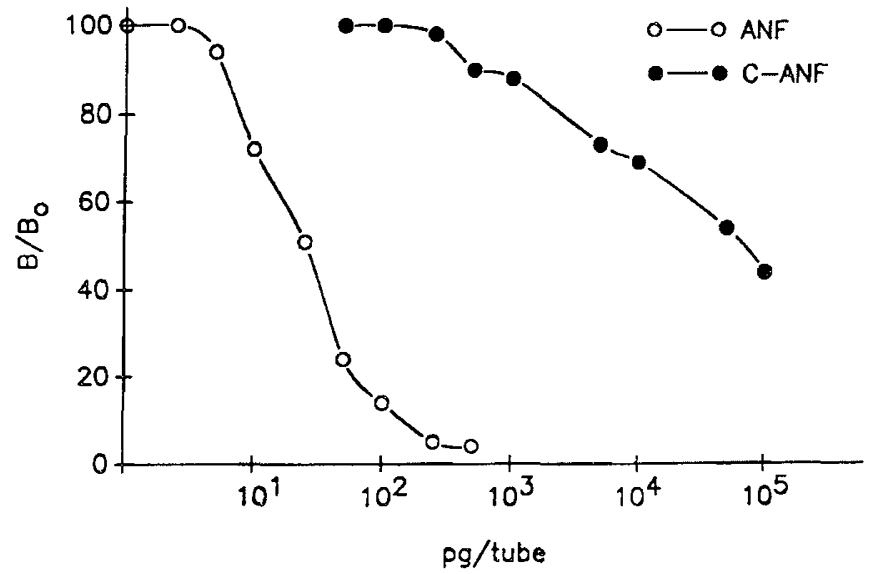

Fig. 1. Competition curve of ANF (1-28) and C-ANF (4-23) for binding to ANF antiserum. $B / B O, \%$ bound relative to maximal binding.

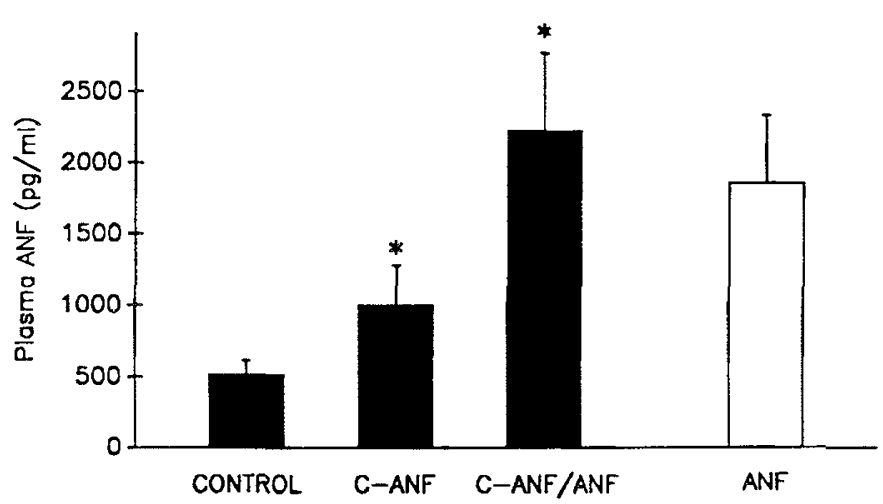

Fig. 2. Mean $( \pm \mathrm{SEM})$ fetal plasma ANF concentrations in response to i.v. C-ANF $(1 \mu \mathrm{g} / \mathrm{min} / \mathrm{kg})$ and C-ANF $/$ ANF $(1 \mu \mathrm{g} / \mathrm{min} / \mathrm{kg}$ and 100 $\mathrm{ng} / \mathrm{min} / \mathrm{kg}$ ) infusion and ANF infusion alone at $100 \mathrm{ng} / \mathrm{min} / \mathrm{kg}$. ${ }^{*}$ Plasma ANF values that are significantly different $(p<0.05)$ from control values.

$$
\text { FBW }(\mathrm{kg})=[0.096 \times \text { gestational age }(\mathrm{d})]-9.2228
$$

Fetal and adult arterial blood samples for ANF determinations were collected at 10,20 , and $30 \mathrm{~min}$ of each of the $30-\mathrm{min}$ infusion periods and placed in tubes containing EDTA $(1 \mathrm{mg} /$ $\mathrm{mL}$ ), Traysylol (250 kallikrein inhibitor units/mL) and soybean trypsin inhibitor ( 50 benzyl-L-arginine ethyl ester units $/ \mathrm{mL}$ ). All samples were centrifuged immediately at $4^{\circ} \mathrm{C}$ and the plasma for ANF assay was separated and stored at $-20^{\circ} \mathrm{C}$ until extracted. The remaining aliquoted plasma was utilized for measurements of osmolality, sodium and potassium concentrations, and ${ }^{3} \mathrm{H}$ inulin activity. Additional blood samples $(0.5 \mathrm{~mL})$ were collected into heparinized tuberculin syringes at the end of each period for immediate measurement of $\mathrm{pH}, \mathrm{PO}_{2}$, and $\mathrm{PCO}_{2}$.

The total volume of fetal blood withdrawn at each sampling (4.0-4.5 mL) was replaced with an equal volume of heparinized maternal blood withdrawn before the study. Arterial blood and 
Table 2. Arterial blood, plasma, and cardiovascular values before, during, and after C-ANF and C-ANF/ANF or ANF infusions in fetal sheep at $114(n=6)$ d gestation*

\begin{tabular}{|c|c|c|c|c|c|}
\hline & Control & $\mathrm{C}-\mathrm{ANF}$ & C-ANF/ANF & Recovery & ANF \\
\hline \multicolumn{6}{|l|}{ Blood } \\
\hline $\mathrm{pH}$ & $7.37 \pm 0.01$ & $7.37 \pm 0.01$ & $7.38 \pm 0.01$ & $7.36 \pm 0.01$ & $7.37 \pm 0.01$ \\
\hline $\mathrm{PO}_{2}(\mathrm{~mm} \mathrm{Hg}) \dagger$ & $23 \pm 1$ & $22 \pm 1$ & $23 \pm 1$ & $25 \pm 2$ & $24 \pm 1$ \\
\hline $\mathrm{PCO}_{2}(\mathrm{~mm} \mathrm{Hg})$ & $46 \pm 2$ & $46 \pm 3$ & $45 \pm 2$ & $46 \pm 3$ & $42 \pm 2$ \\
\hline Hct $(\%)$ & $30 \pm 2$ & $30 \pm 2$ & $31 \pm 2 \ddagger$ & $31 \pm 2 \ddagger$ & $33 \pm 2 \ddagger$ \\
\hline \multicolumn{6}{|l|}{ Plasma } \\
\hline $\mathrm{Na}(\mu \mathrm{mol} / \mathrm{mL})$ & $137 \pm 2$ & $139 \pm 2$ & $138 \pm 2$ & $139 \pm 2$ & $140 \pm 2$ \\
\hline $\mathrm{K}(\mu \mathrm{mol} / \mathrm{mL})$ & $3.9 \pm 0.3$ & $3.7 \pm 0.3$ & $3.8 \pm 0.3$ & $4.1 \pm 0.5$ & $3.6 \pm 0.2$ \\
\hline Osm (mosmol/kg H $\left.\mathrm{H}_{2} \mathrm{O}\right)$ & $291 \pm 2$ & $292 \pm 2$ & $293 \pm 2$ & $293 \pm 2$ & $294 \pm 4$ \\
\hline \multicolumn{6}{|l|}{ Cardiovascular } \\
\hline $\mathrm{MAP}(\mathrm{mm} \mathrm{Hg})$ & $39 \pm 2$ & $38 \pm 2$ & $37 \pm 2$ & $37 \pm 2$ & $37 \pm 1$ \\
\hline Heart rate & $186 \pm 5$ & $193 \pm 9$ & $213 \pm 8 \div$ & $200 \pm 8$ & $194 \pm 2 \ddagger$ \\
\hline
\end{tabular}

* Values are mean \pm SEM. Hct, hematocrit; Na, sodium; $\mathrm{K}$, potassium; Osm, osmolality; MAP, mean arterial blood pressure. $\dagger 1 \mathrm{~mm} \mathrm{Hg}=0.133 \mathrm{kPa}$.

$\ddagger$ Values statistically different from control values, $p<0.05$.
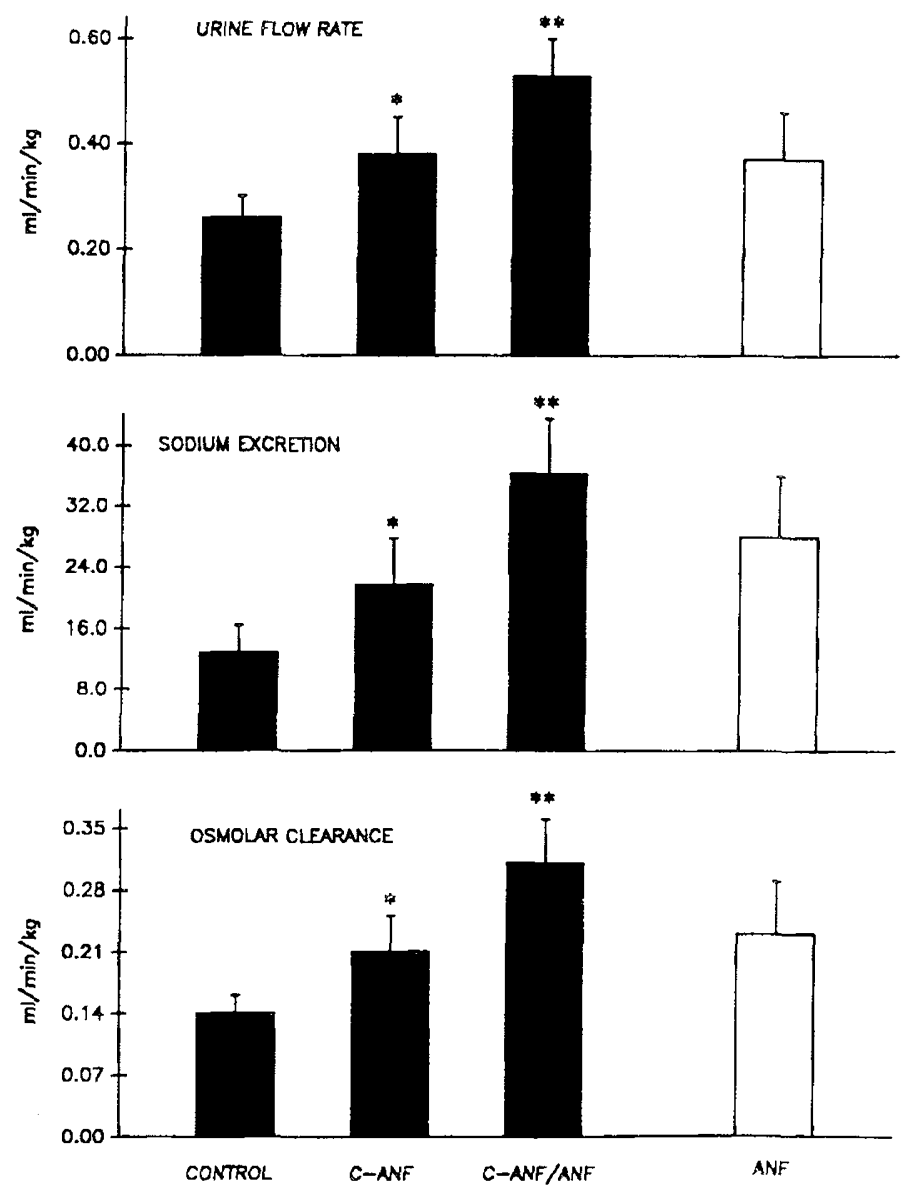

Fig. 3. Effects of C-ANF $(1 \mu \mathrm{g} / \mathrm{min} / \mathrm{kg}), \mathrm{C}-\mathrm{ANF} / \mathrm{ANF}(1 \mu \mathrm{g} / \mathrm{min} / \mathrm{kg} /$ and $100 \mathrm{ng} / \mathrm{min} / \mathrm{kg})$, and ANF $(100 \mathrm{ng} / \mathrm{min} / \mathrm{kg})$ infusion on urine flow rate, sodium excretion, and osmolar clearance in ovine fetal lambs. * Values that are statistically significant from control values, $p<0.05$. $* *$ Values that are significantly different from C-ANF infusion alone ( $p$ $<0.05$ ).

amniotic cavity pressures were monitored continuously by means of a Beckman R-612 physiologic recorder (Beckman Instruments, Irvine, CA) with Statham P23 transducers (Sensormedics, Fullerton, CA). Fetal blood pressure was corrected for amniotic fluid pressure and heart rate was computed from the arterial pulse. At the end of each urine collection period $(10 \mathrm{~min})$, urine volume was measured and aliquots were analyzed for osmolality, sodium and potassium concentrations, and ${ }^{3} \mathrm{H}$-inulin levels.

Analytical methods. Plasma ANF samples were extracted with
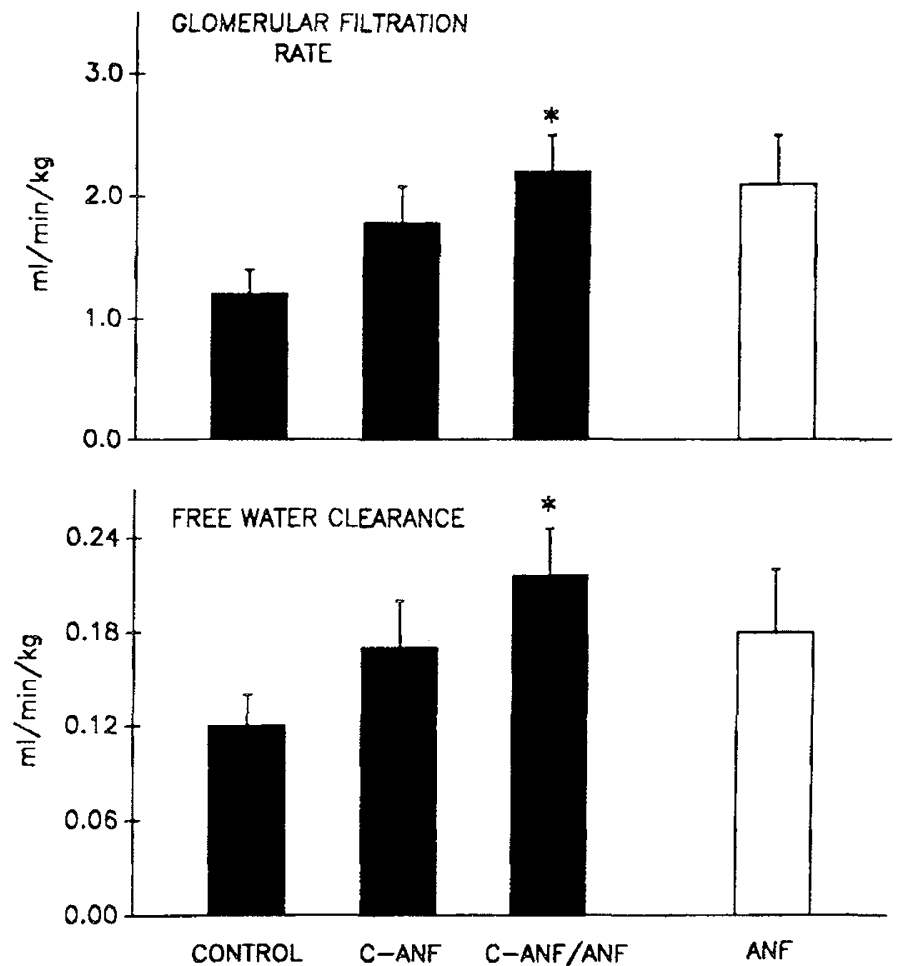

Fig. 4. Effects of C-ANF $(1 \mu \mathrm{g} / \mathrm{min} / \mathrm{kg})$, C-ANF $/$ ANF $(1 \mu \mathrm{g} / \mathrm{min} / \mathrm{kg}$ and $100 \mathrm{ng} / \mathrm{min} / \mathrm{kg})$, and ANF $(100 \mathrm{ng} / \mathrm{min} / \mathrm{kg})$ infusions on GFR and free water clearance in ovine fetal lambs. ${ }^{*}$ Values that are significantly different from control values.

C-18 Sep Pak columns (Waters Associates, Medford, MA) and ANF levels were determined by RIA as previously described (15). The sensitivity of the assay, defined by the least amount of added ANF distinguishable from zero tubes at the $95 \%$ confidence limit, was $2 \mathrm{pg} /$ tube. The intraassay and interassay coefficients of variation were 11 and $13 \%$, respectively.

Blood $\mathrm{pH}, \mathrm{PO}_{2}$, and $\mathrm{PCO}_{2}$ values were determined at $39^{\circ} \mathrm{C}$ with a Radiometer BM 33 MK2-PHM 72 MK2 acid-base analyzer system (Radiometer Co., Copenhagen, Denmark). Plasma and urine osmolalities were measured by freezing point depression using an Advanced Instruments Osmometer (model MO; Advanced Instruments, Inc., Needham Heights, MA). Plasma and urine sodium and potassium concentrations were determined with an Instrumentation laboratory (model 143; Watertown, MA) flame photometer. The concentration of ${ }^{3} \mathrm{H}$-inulin in plasma and urine was assessed in a Beckman LS-355 liquid scintillation counter. 
Table 3. Effect of $0.9 \%$ NaCL infusion on fetal sheep $(n=5)$ *

\begin{tabular}{lcccc}
\hline & \multicolumn{3}{c}{ Min } \\
\cline { 2 - 5 } & 30 & 60 & 90 & 120 \\
\hline $\mathrm{UV}(\mathrm{mL} / \mathrm{min} / \mathrm{kg})$ & $0.12 \pm 0.02$ & $0.13 \pm 0.03$ & $0.12 \pm 0.03$ & $0.12 \pm 0.03$ \\
$\mathrm{UNaV}(\mu \mathrm{mol} / \mathrm{min} / \mathrm{kg})$ & $5.5 \pm 1.6$ & $6.0 \pm 1.6$ & $5.5 \pm 1.5$ & $7.3 \pm 2.7$ \\
$\mathrm{GFR}(\mathrm{mL} / \mathrm{min} / \mathrm{kg})$ & $0.6 \pm 0.2$ & $0.7 \pm 0.2$ & $0.6 \pm 0.2$ & $0.7 \pm 0.2$ \\
$\mathrm{Cosm}(\mathrm{mL} / \mathrm{min} / \mathrm{kg})$ & $0.06 \pm 0.01$ & $0.07 \pm 0.02$ & $0.06 \pm 0.01$ & $0.06 \pm 0.02$ \\
$\mathrm{CH}{ }_{2} \mathrm{O}(\mathrm{mL} / \mathrm{min} / \mathrm{kg})$ & $0.06 \pm 0.02$ & $0.06 \pm 0.02$ & $0.06 \pm 0.01$ & $0.06 \pm 0.02$ \\
\hline
\end{tabular}

* Values are mean $\pm \mathrm{SEM}$. UV, urine flow rate, $\mathrm{UNaV}$, urine sodium excretion; $\mathrm{Cosm}$, osmolar clearance; $\mathrm{CH}_{2} \mathrm{O}$, free water clearance.

Statistics. All values are expressed as the mean \pm SEM. Differences over time were assessed by one-way analysis of variance for repeated measures. Whenever a significant $F$ test of $p<0.05$ was observed, comparisons of the control means to each of the other group means were performed by Dunnett's test $(p<0.05)$. Fetal responses were compared by paired $t$ test as appropriate.

\section{RESULTS}

Maternal arterial measurements. There were no changes from basal values of maternal hematocrit, $\mathrm{pH}, \mathrm{PO}_{2}, \mathrm{PCO}_{2}$, plasma osmolality, or ANF concentrations during the course of the study (Table 1).

Fetal arterial measurements. The antiserum used in the ANF RIA was $100 \%$ cross-reactive with human ANF (1-28 amino acids); cross-reaction with C-ANF was less than $0.02 \%$ on a molar basis (Fig. 1). Because no differences were found in plasma ANF concentrations at 10,20 , and $30 \mathrm{~min}$ of each infusion period, plasma and urinary data were expressed as the mean value of each respective period. Data during ANF infusion alone is presented with the C-ANF infusions; control and recovery data did not differ. Fetal plasma ANF concentrations increased from control values of $477 \pm 45$ to $1067 \pm 297 \mathrm{pg} / \mathrm{mL}(p<0.05)$ during the C-ANF infusion and increased further to $2394 \pm 532$ $\mathrm{pg} / \mathrm{mL}$ during the combined C-ANF/ANF infusion (Fig. 2). The mean plasma ANF concentration observed during the combined C-ANF or C-ANF/ANF infusion was not different than obtained with ANF infusion alone $(1866 \pm 482 \mathrm{pg} / \mathrm{mL})$. The estimated mean fetal $\mathrm{PC}_{\mathrm{ANF}}$ during the combined C-ANF/ANF infusion was $77 \pm 16 \mathrm{~mL} / \mathrm{min} / \mathrm{kg}$ versus $68 \pm 15 \mathrm{~mL} / \mathrm{min} / \mathrm{kg}$ with ANF infusion alone.

The infused $\mathrm{C}-\mathrm{ANF}$ and combined C-ANF/ANF had no significant effects on fetal arterial $\mathrm{pH}, \mathrm{PO}_{2}, \mathrm{PCO}_{2}$, or mean arterial blood pressure (Table 2). The combined C-ANF/ANF infusion produced significant increases in fetal heart rate and hematocrit not evident with the C-ANF infusion. A similar response in fetal heart rate and hematocrit was observed during ANF infusion alone (Table 2).

In response to the C-ANF infusion, fetal urine flow rate, sodium excretion, and osmolar excretion increased significantly $(p<0.05)$ over basal values (Fig. 3). The combined C-ANF/ ANF infusion evoked increases in urine flow rate, sodium excretion, and osmolar excretion values that were significantly greater $(p<0.05)$ than were observed in response to C-ANF alone. The mean responses of fetal urine flow rate, sodium excretion, and osmolar excretion to ANF infusion alone did not differ from the responses obtained with C-ANF or the combined C-ANF/ANF infusion (Fig. 3).

As shown in Figure 4, increases in both GFR and free water slearance were noted during the C-ANF infusion. However, the values did not differ significantly from control values. The comsined C-ANF/ANF infusion evoked further increases that were ignificantly greater $(p<0.05)$ than control values. The GFR ind free water clearance responses induced by ANF infusion llone also were significantly greater than control values but did ot differ from the responses observed during combined C-ANF/ ANF infusion.
No changes in fetal plasma ANF levels or renal function were observed during infusion of $0.9 \% \mathrm{NaCl}$ in fetal sheep (Table 3).

\section{DISCUSSION}

The ANF receptor exists in several forms, including a 120 - to $135-\mathrm{kD}$ guanylate cyclase $\left(\mathrm{R}_{1}\right)$ and a $66-$ to $70-\mathrm{kD}$ truncated protein lacking most of the intracellular domain $\left(R_{2}\right)(4,5)$. The former binds the major circulating form of ANF (ANF99-196), and binding results in the activation of guanylate cyclase and increased cyclic GMP production (4). The truncated receptor, the more abundant receptor form in most tissues, accepts a wider range of ANF structures, but ligand binding does not evoke cyclic GMP generation $(16,17)$. When originally described, the $\mathrm{R}_{2}$ receptor was proposed to modulate circulating ANF levels by serving as a storage/clearance site $(7,18)$. More recently, ANF$R_{2}$ receptor activation has been reported to stimulate phosphoinositol hydrolysis (8) and inhibit the adenylate cyclase/cAMP system (9). These observations suggest that ANF- $R_{2}$ receptors exert direct biologic effects via the phosphoinositol system and modulate the adenylate cyclase system to other hormones. However, the physiologic importance of these effects remains to be investigated.

The dose of C-ANF used in our study was previously shown to produce a biologic effect in adult small animals $(7,19)$. In agreement with these earlier observations, C-ANF infusion into fetal sheep evoked significant increases in fetal plasma ANF concentration and the combined C-ANF/ANF infusions produced a further increase in fetal ANF concentration $(1067 \pm 297$ to $2394 \pm 532 \mathrm{pg} / \mathrm{mL}$ ). Because C-ANF is not immunoreactive in the ANF RIA system, the increase in plasma ANF concentration observed during C-ANF infusion represents either increased ANF secretion or occupation of ANF- $R_{2}$ receptors with displacement of endogenous ANF $(7,19)$. The control (saline) infusion did not evoke ANF release, and there is no evidence that C-ANF stimulates cardiac ANF secretion. The observed increases in urine flow rate, GFR, osmolar clearance and sodium excretion are consistent with a C-ANF-induced increase in plasma ANF receptors. However, because the fetal plasma ANF levels and $\mathrm{PC}_{\mathrm{ANF}}$ values were statistically similar during $\mathrm{ANF}$ alone and combined C-ANF/ANF infusion $(2394 \pm 532$ versus $1866 \pm 482$ $\mathrm{pg} / \mathrm{mL}$, and $68 \pm 15$ versus $77 \pm 16 \mathrm{~mL} / \mathrm{kg} / \mathrm{min}$, respectively), these data do not support a clearance role for $R_{2}$ receptors in the fetus.

The increases in urine flow rate, sodium excretion, and osmolar clearance observed in response to C-ANF infusion apparently resulted from increased plasma ANF concentrations as already discussed. Although not statistically significant, mean GFR and free water clearance increased 49 and $27 \%$ during CANF infusion relative to the control period. The combined CANF/ANF infusions evoked further significant increases in urine flow rate, sodium excretion, osmolar clearance, GFR, and free water clearance (Figs. 3 and 4). However, the responses to combined C-ANF/ ANF infusion were not different from the effects of ANF infusion alone, suggesting that a plateau in the renal response to ANF is achieved at plasma ANF levels less than $1800 \mathrm{pg} / \mathrm{mL}$. The significant fetal renal responses to increased plasma ANF concentrations are consistent with previous 
studies of fetal lambs of similar ages (20), but contrast markedly with the result of Robillard et al. (21). This apparent discrepancy in responses was recently explained by our demonstration that the fetal renal response to ANF decreases between 115 and 130 d gestation (22).

In adult rats, $C$-ANF decreases the ANF volume of distribution and plasma ANF clearance, presumably by occupying ANF- $\mathbf{R}_{2}$ receptors (18). Previously, our laboratory demonstrated a 2-fold higher $\mathrm{PC}_{\mathrm{ANF}}(120 \pm 32$ versus $59 \pm 12 \mathrm{~mL} / \mathrm{min} / \mathrm{kg})$ in older (131 d) ovine fetuses compared with adult ewes (23). ANF clearance was relatively reduced in the younger fetuses in the present study $(168 \pm 15 \mathrm{~mL} / \mathrm{kg} / \mathrm{min})$ and similar to the adult value. Although, the reason for the increase in $\mathrm{PC}_{\mathrm{ANF}}$ with advancing fetal age is not clear, differing clearance mechanisms and/or changes in the ratio of $R_{1}$ to $R_{2}$ receptors may contribute to the observed maturational decreases in renal responsiveness to ANF (22).

The kidneys and lungs have been proposed as primary sites of adult ANF metabolism $(24,25)$. C-ANF has been observed to bind over $90 \%$ of renal glomerular ANF binding sites in the adult (7), suggesting that the majority of glomerular ANF binding sites represent ANF- $R_{2}$ receptors. Because fetal renal and pulmonary blood flows are low relative to adults, renal and pulmonary ANF clearance are unlikely to be major sites for fetal ANF plasma clearance. However, developmental increases in fetal, newborn, and adult rabbit glomerular ANF binding capacity suggest that $R_{2}$ receptor density increases with age (Castro $R$, Leake RD, Ervin MG, Ross MG, Fisher DA, unpublished data). A high density of ANF receptors in the placental vasculature (810 ) and the umbilical arterio-venous differences in ANF plasma concentration $(26,27)$ suggest a placental role in ANF degradation or clearance, and available evidence suggests that $R_{1}$ receptors predominate in placental tissue (28). There is no information at present regarding changes in abundance or type of placental ANF receptors with advancing gestation. Other pathways of ANF degradation, including enzymatic pathways, may differ in the fetus and adult, but there is no information at present regarding these systems in fetal animals (29).

There were no changes in blood pressure observed during any portion of our study. The absence of an ANF-induced vasorelaxant effect by either the C-ANF or C-ANF/ANF infusion is not surprising. Robillard et al. (21) and Ervin et al. (23) have previously reported a lack of fetal arterial pressure response to ANF infusion. Differences in ANF vascular responsiveness secondary to differences in ANF receptor subpopulations in the developing vascular endothelium may be accountable. Alternatively, an increased fetal cardiac output due to fetal tachycardia and the presence of an elevated intravascular volume (relative to the adult), and the low-resistance placental vascular bed may serve to diminish an ANF-induced hypotensive effect in the fetus.

In summary, C-ANF infusion increases endogenous fetal ANF concentrations and produces natriuretic and diuretic responses in the early 3rd-trimester fetus. Although the renal response was further potentiated by the coadministration of ANF, the renal response did not differ from that of ANF administered alone at the same dose. These findings are consistent with a C-ANFinduced displacement of ANF from a second $R_{2}$ receptor pool. However, binding of C-ANF to $R_{2}$ receptors did not alter ANF clearance. The physiologic role of $R_{2}$ receptors remains to be determined. Future studies detailing the response to C-ANF in the more mature fetus and characterization of ANF receptor subtypes will provide further evidence for the role of ANF in fetal fluid and volume regulation during maturation.

Acknowledgments. The authors thank Glenda Calvario, Lisa Miller, and Jim Humme for their assistance in the completion of these studies and Sharon Schuler for her assistance in the preparation of the manuscript.

\section{REFERENCES}

1. Cantin M, Genest J 1985 The heart and the atrial natriuretic factor. Endocr Rev 6:107-127

2. DeBold AJ 1985 Atrial natriuretic factor: a hormone produced by the heart Science 230:767-770

3. Jacobs JW, Vlasuk GP, Rosenblatt M 1986 Atrial natriuretic factor receptor. Endocrinology and Metabolism Clinics of North America, Vol 16. WB Saunders, Philadelphia, pp 63-77

4. Huang CL, Ives HE, Cogan MG 1986 In vivo evidence that cGMP is the second messenger for atrial natriuretic factor. Proc Natl Acad Sci USA 83:8015-8018

5. Porter JG, Scarborough RM, Wank X, Schenk D, McEnroe GA, Kang LL, Lewicki JA 1989 Recombinant expression of a secreted form of the atrial natriuretic peptide clearance receptor. J Biol Chem 264:14179-14184

6. Scarborough RM, Schenk DB, McEnroe GA, Arfsten A, Kang LL, Schwartz K, Lewicki JA 1986 Truncated atrial natriuretic peptide analogs: comparison between receptor binding and stimulation of cyclic GMP accumulation in cultured vascular smooth muscle cells. J Biol Chem 261:12960-12964

7. Maack T, Suzuki M, Almeida FA, Nussenzveig D, Scarborough RM, McEnroe GA, Lewicki JA 1987 Physiological role of silent receptors of atrial natriuretic factor. Science 238:675-678

8. Hirata M, Chang CH, Murad F 1989 Stimulatory effects of atrial natriuretic factor on phosphoinositide hydrolysis in cultured bovine aortic smooth muscle cells. Biochim Biophys Acta 1010:346-351

9. Anand-Srivastava MB, Sairam MR, Cantin M 1990 Ring-deleted analogs of atrial natriuretic factor inhibit adenylate cyclase/cAMP system. J Biol Chem 265:8566-8572

10. Hatij GC, Grogans DM 1988 Atrial natriuretic peptide receptors in sheep cotyledons. Am J Obstet Gynecol 159:1337-1340

11. Hatjis GC, Grogans DM 1989 Atrial natriuretic peptide receptors in guinea pig placentas. Am J Obstet Gynecol 161:493-496

12. Hatjis GC, Grogans DM 1988 Atrial natriuretic peptide receptors in norma human placentas. Am J Obstet Gynecol 159:587-59

13. Castro R, Ervin MG, Ross MG, Leake RD, Fisher DA 1989 Characterization of ovine fetal glomerular receptors for atrial naturetic factor (ANF). Pediat Res 25:273A(abstr)

14. Robillard JE, Matson JR, Sessions C, Smith FG 1979 Developmental aspects of renal tubular reabsorption of water in the lamb fetus. Pediatr Res 13:11721176

15. Castro L, Lam RW, Ross MG, Ervin MG, Leake RD, Hobel CJ, Fisher DA 1988 Atrial natriuretic peptide in the sheep. J Dev Physiol 10:235-246

16. Nussenzveig D, Scarborough RM, Lewicki JA, Maack T 1989 Clearance receptors of atrial natriuretic factor in isolated glomeruli and mesangial cells in culture. Proc Annu Meet AM Soc Nephrol 20:132(abstr)

17. Michel H, Meyer-Lehnert H, Backer A, Stelkens H, Kramer H 1990 Regulation of atrial natriuretic peptide receptors in glomeruli during chronic salt loading. Kidney Int 38:73-79

18. Almeida FA, Suzuki M, Scarborough RM, Lewicki JA, Maack T 1989 Clearance function of type $C$ receptors of atrial natriuretic factor in rats. Am J Physiol 256:R469-R475

19. Jin H, Chen Y, Yang R, Jackson RM, Oparil S 1990 Atrial natriuretic peptide clearance receptor agonist lowers pulmonary pressure in hypoxic rats. J Appl Physiol 68(6):2413-2418

20. Shine P, MCDougall JG, Towstoless MK, Wintour EM 1987 Action of atrial natriuretic peptide in the immature ovine kidney. Pediatr Res 22:11-15

21. Robillard JE, Nakamura KT, Varille VV, Andresen AA, Matherne GP, Vanorden DE 1988 Ontogeny of the renal response to natriuretic peptide in sheep. Am J Physiol 254:F634-F641

22. Castro R, Ervin MG, Leake RD, Ross MG, Fisher DA 1991 Fetal renal response to atrial natriuretic factor decreases with maturation. Am J Physiol (in press)

23. Ervin MG, Ross MG, Castro R, Sherman D, Lam RW, Castro L, Leake RD Fisher DA 1988 Ovine fetal and adult atrial natriuretic factor metabolism. Am J Physiol 254:R40-R46

24. Turrin M, Gillis N 1986 Removal of atrial natriuretic peptide by perfused rabbit lungs in situ. Biochem Biophys Res Commun 140:868-873

25. Suzuki M, Almeida FA, Nussenzveig DR, Sawyer D, Maack T 1987 Binding and functional effects of atrial natriuretic factor in isolated rat kidney. Am J Physiol 253:F917-F928

26. Yamaii T, Hirai N, Ishibashi M, Takaku F, Yanaihara F, Nakayama T 1986 Atrial natriuretic peptide in umbilical cord blood: evidence for a circulating hormone in human fetus. J Clin Endocrinol Metab 63:1414-1417

27. Castro LC, Arora CP, Roll KE, Sassoon DA, Hobel CJ 1989 Perinatal factors influencing atrial natriuretic peptide levels in umbilical arterial plasma at the time of delivery. Am J Obset Gynecol 161:623-627

28. McQueen J, Kingdom JCP, Jardine AG, Connell JMC, Whittle MJ 1990 Vascular angiotensin II and atrial natriuretic peptide receptors in normal and growth-retarded human placentae. I Endocrinol 126:341-347

29. Seymour AA, Fennel SA, Swerdel JN 1989 Potentiation of renal effects of atrial natriuretic factor $(99-126)$ by SQ 29,072 . Hypertension 14:87-97 